\title{
English Learning that Fosters Positive Attitudes
}

\author{
Y.B. Gunawan \\ ELESP - Sanata Dharma University
}

\begin{abstract}
This article discusses the integration of English teaching and attitude components. In the new school curriculum the attitude or affective domain components are considered very important as we can see in the Core Competence and Basic Competence. The English teacher should be able to teach English while paying attention to the attitude components. This article aims to show that the two aspects can be done together. The assumption taken is that while teaching English, the teacher also develops the students' affective domain/deals with the learners' attitude. What remains to be done is that the English teacher should be able to identify his/her theoretical orientation that he/she has with regard to language, language learning, and educational cultural viewpoints. One of these viewpoints language learning - is further elaborated in H.D. Brown's second language learning principles. With these major concepts and principles the English teacher is expected to be able to integrate the English teaching-learning process with the affective-domain related process.
\end{abstract}

Keywords: attitude, affective domain, character building, language learning viewpoint, second language learning principles

\section{INTRODUCTION}

Teaching English that incorporates attitudinal aspects is not easy. An English teacher may design a grammar lesson that contains activities in which learners learn a grammatical point and at the same time they do it in a cooperative learning manner to enhance cooperativeness among themselves. Although it seems difficult to integrate a grammatical point and a certain attitude in one lesson, a lot of teachers, aware or not, do this, and many are successful in doing so. Without knowing why, we often see that some English teachers in a school are considered as good English instructors. What we are usually aware of is that good English teachers have a lot of experiences, they can make their students speak actively in class, most or all of their students pass the final examination, or the students love the teachers' ways of teaching and behaving in class. These examples show that there may be strengths or some power possessed by successful English teachers that we do not exactly know. Nevertheless, one thing that we often find is that in a successful English instruction the students usually have some positive attitudes that may have been fostered by the English teacher (and surely also by the other teachers and the school environment). For example, they show that they are active, they enjoy learning English, they ask questions, they can work together, and they do not give up easily.

From this observation, we may assume that learning language skills like speaking and writing cannot be separated from having positive attitudes shown in, among other things, the students' discipline, initiative, cooperativeness, and studying habits. English teachers not only teach language skills and elements but also "teach" attitudes although they may do so without being aware or without having explicit objectives. It is then further assumed that the students will perform better if the English teacher consciously pays attention to attitude-related objectives. This assumption is not new. English teachers are familiar with methods that emphasize attitude development, such as Cooperative Language Learning and Multiple Intelligence. In those methods English teachers teach English by making use of activities and techniques that are connected to the development of students' attitudes to reach maximum results. The new school curriculum explicitly contains goals and objectives dealing with the learners' attitude 
development (KI-KD Kurikulum 2013, 2013). It is expected that by using the new curriculum schools will be able to prepare young Indonesians to face new challenges in the $21^{\text {st }}$ century, and this will largely be dependent upon how they are able to make use of positive attitudes effectively. This article aims to show the reader that actually learning English skills and developing the learners' positive attitudes can be done together. The terms 'attitude' and 'affective domain' used here are often interchangeable to refer to the major component of 'character building'.

\section{THE INTEGRATION OF ATTITUDE COMPONENTS INTO THE CURRICULUM}

In fact, the development of the learners' attitude in class is part of character building, which has been re-emphasized in general education recently and integrated into the curriculum. Ministerial Regulation No. $23 / 2006$ on competence standard of school graduates is closely related to character building. Through this regulation the National Education and Culture Minister urged all schools to build their students' character more seriously. School graduates should show selfconfidence, adhere to social norms, appreciate diversity in terms of religion, culture, race, and socio-economic group. In the past, character building in schools was introduced to students with little effort to integrate it into the whole curriculum. It is now expected that character building is integrated into each school subject and into co-curricular and extra-curricular activities. The school management should be involved in the planning, implementation, and control of character building programs. Some aspects of the character that should be developed include independence, selfconfidence, tolerance, social sensitivity, democratic spirit, and responsibility as they are contained in Government Regulation No $17 / 2010$ on education management (Kementerian Pendidikan Nasional, 2010).

School subjects like English are expected to integrate character building into their goals and processes. The Indonesian National Qualification Framework (INQF/KKNI) documents state that the affective domain, the major component in character building, should become the hub of the learning outcome wheel, whose parts consist of science, knowledge, know-how, skills, and, at the center, affection (Ditjen Dikti, 2011: 11). In general, the affective domain includes processes that enable the learner to act as a citizen who loves his/her country and supports world peace, who has high social sensitivity and concern, who appreciates a variety of regional cultures, points of view, beliefs, religions, and other people's opinions, and who respects law enforcement and has the spirit to prioritize the interests of the nation and society (Kementerian Pendidikan Nasional, 2010: 5). English teachers are challenged to integrate these affective factors into English classes. Consequently, English learning is now closely associated with learning to be social beings who are self-fulfilled or self-actualized; in other words, it cannot be separated from character building. The CTL/PAIKEM approach, with which school teachers are familiar, could not be effectively implemented without taking affective factors into serious consideration. The new school curriculum (Kurikulum 2013) also gives these affective factors high priority. The syllabus of any subject developed from the curriculum always starts with affective factoror attitude-related core competence and basic competence before it deals with other competence related to cognitive and psychomotor domains (Hasan, 2013: 12-30).

The following is an example that shows the affective domain is essential in educating young learners. Although the example is not specifically connected to English teaching, here we may realize the essential role and broad scope of the affective domain in education.

The Attitude Components in Sanata Dharma Education

To respond to the nationwide move of character building, the university where the writer teaches (Sanata Dharma University/USD), has been developing a model of character building. The model is in line with the 2010-2014 Strategic Plan of the National Education Ministry and is based on the Ignatian pedagogy (Kuntoro Adi, et al, 2010: 6-19). Referring to the Ministry's Strategic Plan, two educational viewpoints related to character 
building that USD has tried to develop involve the empowerment of the human being as a whole and learning for life which centers on the learner. The Strategic Plan of the National Education Ministry mentions four aspects of the idealized intelligent Indonesian: spiritually intelligent, emotionally and socially intelligent, intellectually intelligent, and kinesthetically intelligent.

While the goals above are recognized by USD, the model of character building that USD has tried to develop is based on the Ignatian Spirituality. The implementation of the spirituality is called Ignatian pedagogy, which can be stated as the following (summarized from Kuntoro Adi, et al, 2010: 2829):

a. The teacher serves his/her students and helps them individually develop their internal ability.

b. The students should be active in their studies in which discovery and creativity are given priority.

c. The relationship between the teacher and his/her students is personal and continuing.

d. The syllabus and teaching-learning activities should be in accordance with the students' ability levels, and the material contents are logically sequenced.

e. Previews and reviews are regularly done for better mastery and assimilation, and deeper viewpoints.

This implementation of Ignatian pedagogy surely contains some major attitude components, such as helping students develop their internal ability, being active so that discovery and creativity emerge, personal continuing relationship between the teacher and students, and adapting contents to the students' ability levels, which implies the teacher's recognition of learners' differences.

Character building developed at USD makes use of the three major components of its educational process: curricular, cocurricular, and extra-curricular activities. Through these activities students are expected to have whole, strong character in the three domains: competence, conscience, and compassion. The second and third domains contain attitude or affective-domain components, such as having a passion for social justice (conscience) and responding to those who are in greatest need (compassion) (P3MP-LPM Universitas Sanata Dharma, 2012: 38-39).

Realizing the importance and the broad scope of character building shown in the example above, English teachers, though in a narrower scope, are challenged to integrate the affective domain into their teaching activities. They may be overwhelmed by this, but it is expected that they can do it both naturally and by design.

\section{English Teaching-Learning Process that Builds Character}

Reading the following objectives, a high school English teacher who is preparing a conversation session may find it difficult to find strategies and activities to reach them: $\mathrm{Be}$ thankful for the opportunity to learn English as an international lingua franca, realized in learning enthusiasm (1.1) and show honesty, discipline, self-confidence and responsibility in communicating with the teacher \& classmates (2.2) (taken from Kurikulum 2013). Before finding strategies and activities, he/she should elaborate these general objectives (called basic competence) into some measurable learning indicators, such as showing honesty in expressing apology orally to another person in class and/or in a group, showing high discipline in expressing their self-identity orally in class and/or in a group, and showing high selfconfidence in expressing disagreement orally in class and/or in a group. Based on these learning indicators, the teacher then has to plan appropriate strategies and activities (and later assessment types).

How can the teacher make his/her students honest, highly disciplined, and selfconfident? This will depend on the teacher's experiences, teaching-learning process knowledge and skills, and individual preference. In other words, different teachers may have different strategies and activities although they have the same goals and objectives. There may be no standard way to reach the same goals and objectives. One 
teacher suggests a strict drilling practice should be given first before giving a freer communicative activity in order to develop the students' discipline in doing activities in class and in using some fixed expressions in speaking English. Another teacher may emphasize the value of self-confidence by asking the students to communicate in groups to practice making apology. English teachers seem to have different beliefs, approaches, strategies, and techniques. Will this make the teaching-learning process unsystematic and even messy when the affective domain-related goals and objectives are involved? The writer believes that it will not.

Some general guidelines for English teachers are needed in order to make the teaching-learning process more systematic, better planned, and of course filled with enthusiasm. The writer agrees that each teaching-learning process is personal, contextual, and inherently different, yet it is also systematic and its major components can be identified. The following are some guidelines that may enable us to integrate the affective domain and English skills. (Note that not all familiar, obvious suggestions like 'begin with goals and objectives' are mentioned).

- Have theoretical viewpoints that become our basic teaching-learning process orientation

We follow what has been suggested by language teaching experts for many years. A syllabus or lesson plan should have a basic theoretical orientation or approach. Dubin and Olshtain suggest that when we design a course we should have theoretical viewpoints. In their design model, which was specifically written for language teaching and learning, any language learning curriculum has general goals that reflect three viewpoints: a viewpoint on the nature of language, a viewpoint on the nature of language learning, and an educational-cultural viewpoint (1986, p. 34). Those viewpoints as part of general goals in a design process are essential in any language learning design.

In regard to a language viewpoint, Dubin and Olshtain subscribe to communicative language teaching theory and name the viewpoint as sociocultural views on the nature of language (1986: 69-70). The most important concept developed here is communicative competence. Knowing a language includes not only the form of the language, but also knowledge of what to say, when, how, where, and to whom.

In regard to a language learning viewpoint, we may subscribe to Brown's learning principles. The principles are divided into three major ones: the cognitive principles, the affective principles, and the linguistic principles. These three major principles will be the topic of the next guideline point.

An educational-cultural viewpoint gives a context to a language learning curriculum. Dubin and Olshtain mention humanistic views of education for the development of communicative goals. Such a curriculum emphasizes sharing of control, negotiation, and joint responsibility by learners. In this type of curriculum thinking, feelings, and action should be stressed. The main goal is to develop the whole person within a human society ( $\mathrm{McNeil}$ as quoted by Dubin and Olshtain, 1986: 75). Besides, the humanistic curriculum influences the emphasis on learner-centered pedagogy, which is in line with what has been suggested in recent documents published by The Education and Culture Ministry.

In the three viewpoints above the affective domain plays a big role. Teaching a language cannot be separated from character building. Although the following statement sounds like jumping to conclusions, we may state this with confidence: a successful English teacher (who is usually aware of his/her version of theoretical viewpoints) develops his/her students' character while the students are doing learning activities that he/she has arranged.

- Use a second language learning principle to guide our decision to use an appropriate activity, technique, and assessment type

Whatever activities are used, an English teacher should be familiar with important learning principles that become the bases for his/her choice of activties, techniques, and assessment types. The writer chooses Brown's second language learning 
principles (Brown, 2001: 55-70) to guide an English teacher to make practical decisions with regard to techniques, activities, and assessment types. They are chosen because they are simple and many have attitude development contents. In the cognitive principles, Brown uses terms, such as automaticity, meaningful learning, the anticipation of reward, and intrinsic motivation, for his first set of major learning principles. In the affective principles, language ego, self-confidence, risk taking, and the language-culture connection become the key terms. The last set of major principles - the linguistic principles - deal with native language effect, interlanguage, and communicative competence. The summary of each principle in these three sets of major second language learning principles can be seen in the appendix of this article.

How can the teacher make use of a learning principle to decide an appropriate activity? In a speaking class, for example, the teacher uses communicative materials and activities in order to attain learning indicators that have been formulated. In the teachinglearning activities the teacher should give students opportunities to communicate, and their efforts to speak should be appreciated, not be punished. Students are encouraged to produce and speak the target language. They are asked to tolerate a classmate having a problem with fluency, grammar, or pronunciation. They should be accustomed to hearing different dialects (accents), pronunciations, styles, and even mistakes. In other words, they are encouraged to respect one another. This is basically the second language learning principle identified by Brown: Learners should be encouraged to initiate communication and their risky attempts to communicate should be positively responded (Brown, 2001: 56). The teacher should be aware that the teaching-learning process is based on an affective domainrelated learning principle, like the one above.

- Select an activity, technique, and assessment type that enhance both English skills and the learner's positive attitude development
After knowing our own theoretical viewpoints and second language learning principles, we are expected to be able to make decisions at the operation level. The basic assumption taken in this article is that to achieve the goal of integrating English skills and the affective domain there is no single strategy, procedure, or method offered to the reader. If an English teacher is already familiar with constructivist education, Contextual Language Learning, Communicative Language Teaching and many other modern language teaching methods and approaches, hopefully he/she can wisely select appropriate activities and assessment types that enhance both English skills and the learner's positive attitude development. Another important point is that the teacher can still use a familiar (traditional or communicative) technique or activity, but, while planning, he/she is aware of a major language learning principle and tries to apply it in selecting an appropriate activity and assessment type.

\section{CONCLUSION}

Teaching is an art. It is often misunderstood by those who are not directly involved in this art. Teaching English skills like speaking and writing is also an art. Teaching language skills and intergrating the affective domain into it is surely an art too. It is not easy for English teachers to plan and teach a lesson that deals with inexact language use and fluid human character. Asking an English teacher or a teacher of any subject to make a detailed plan of the lesson and teach according to a correct procedure is not what is intended here. What is offered here is asking the English teacher to be aware of important concepts and viewpoints that can be useful for him/her in integrating English skills and attitude-related objectives in a lesson. The design and procedure to do this are not the main concern because the teacher should first realize the importance of integrating character building into a lesson and know basic, theoretical concepts that will guide his/her instructional choices at the operation level. This is not a guideline that will be used to face demands from the local educational authorities who usually want detailed, administrative written documents. The assumption taken in this 
article is that the teacher should know basic concepts and principles (e.g. second language learning principles) first. However, the writer admits that there are still some other basic concepts (e.g. elaboration of educationalcultural viewpoint) that have not been included here. To really be familiar with language learning concepts and principles, we could share our teaching experiences with other teachers in a workshop, conference, or perhaps just an informal meeting with colleagues.

\section{REFERENCES}

Brooks, J. G. and M.G. Brooks. (1993). In Search of Understanding: The Case for Constructivist Classrooms. Alexandria, VA: ASCD.

Brown, H. D. (2001). Teaching by Principles: An Interactive Approach to Language Pedagogy. $2^{\text {nd }}$ ed. New York: Addison Wesley Longman, Inc.

Ditjen Dikti. (2011). "Kebijakan Ditjen Pendidikan Tinggi tentang KKNI dan Arah Kurikulum LPTK." www. staff.uny.ac.id/.../Dirjen\%20Dikti_... Retrieved on October 13, 2012.

Dubin, F. and E. Olshtain, (1986). Course Design. Cambridge: Cambridge University Press.

Hasan, H.S. Hamid. 2013. "Informasi Kurikulum 2013" www.upi.edu/.../Informasi\%20Kurikulum\%202013... Retrieved on September 20, 2013.

Kementerian Pendidikan Nasional. (2010). Panduan: Pendidikan Karakter di Sekolah Menengah Pertama. goeroendeso.files.wordpress.com/2011/09/panduan-pendidikan-karakter-dismp.pdf. Retrieved on July 21, 2012.

KI-KD Kurikulum 2013 Bahasa Inggris SMA Kelas X. https://docs.google.com/file/d/OBX65QFtfGfcZE... Retrieved on January 21, 2014.

Kuntoro Adi, C, Ig. Aris Dwiatmoko, Minto Istono, Setya Tri Nugraha, and E. Maryarsanto P. (2010). Model Pendidikan Karakter. Yogyakarta: Universitas Sanata Dharma.

P3MP-LPM Universitas Sanata Dharma. (2012). Model Pembelajaran Berbasis Pedagogi Ignasian. $2^{\text {nd }}$ ed. Yogyakarta: Universitas Sanata Dharma.

Richards, J. C. and T.S. Rodgers. (2001). Approaches and Methods in Language Teaching $2^{\text {nd }} e d$. Cambridge: Cambridge University Press.

\section{Appendix}

The second language learning principles according to H.D. Brown (2001) are divided into three major ones: the cognitive principles, the affective principles, and the linguistic principles. The following is the writer's summary from the author's book, pp. 55-70:

First, the cognitive principles consist of five principles: automaticity, meaningful learning, the anticipation of reward, intrinsic motivation, and strategic investment. In order to efficiently reach automaticity, the functional purposes of language should be the focal point. Too much focus on analyzing language forms hinders automaticity a great deal. Meaningful learning should be created by exploiting the learner's existing knowledge, background, interests, and goals. This will lead toward his/her better long term retention. The anticipation of reward means that the learner is driven to act when/in anticipation of receiving praise, encouragement, supportive action, and other techniques of giving reward. Expecting to be given reward, he/she is likely to learn more enthusiastically. The learner's intrinsic motivation will emerge by making the learning process interesting, useful, and challenging, a principle that any teacher will agree with but that is hard to implement. The assumption in strategic investment is that each learner has his/her own personal battery of strategies for 
comprehending and producing language. The learning process should recognize this and individual attention is needed. A variety of techniques is needed to 'serve' different strategies all learners have.

Second, the affective principles consist of four principles: language ego, self-confidence, risk taking, and the language-culture connection. In order to pay attention to learners' language ego a supportive attitude on the part of the teacher is necessary. A learner may feel silly, humiliated, or unsure in face-to-face communication, and the teacher's and classmates' patience and empathy are needed to minimize these negative feelings. The learner's self-confidence is needed in order to be successful in accomplishing a task. Verbal and non-verbal assurances to learners are needed. Easy to more difficult techniques also help the learner build a sense of accomplishment. Risk taking is required in using language for meaningful purposes and, therefore, all learners should be encouraged to initiate communication. Their risky attempts to communicate should be positively responded. The languageculture connection refers to the fact that learning a language cannot be separated from learning the culture of its speakers. Cross-cultural understanding is, accordingly, very important for language learners. Certain activities and materials related to language and culture should be included.

Third, the linguistic principles consist of the native language effect, interlanguage, and communicative competence. To reduce the interfering native language effects on production and comprehension of the target language, thinking directly in the target language is recommended. The use of translation should be minimized. A learner's systematic interlanguage errors are indicators that innate language acquisition abilities are 'alive and well' and still developing. Feedback from the teacher should encourage him/her to produce the target language, not to discourage him/her from speaking. The last linguistic principle refers to the conviction that all learning efforts should be directed towards the achievement of the learner's communicative competence. Language use, fluency, authentic language and contexts, and the learner's need to apply what he/she has learnt to real world contexts are essential ways of achieving communicative goals. All the second language learning principles above are not meant to be exhaustive, especially related to the character building-related objectives, but they are sufficient for the initial attempt to give guidelines for the integration of English learning and character building implementation. 